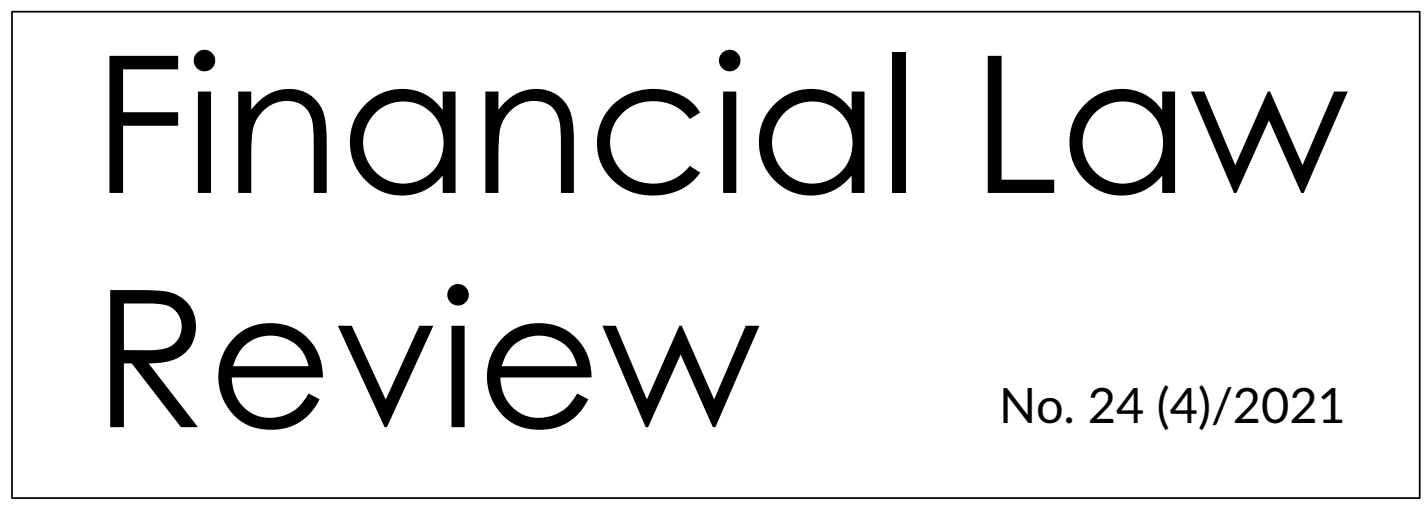

UNIVERSITY OF GDAŃSK • MASARYK UNIVERSITY • PAVEL JOZEF ŠAFÁRIK UNIVERSITY • UNIVERSITY OF VORONEZH http://www.ejournals.eu/FLR

Michal JANOVEC

\title{
HOW TO REDUCE STATE EXPENDITURES WITH SINGLE RESOLUTION MECHANISM
}

\begin{abstract}
State aid is one of the wrong ways how to help any private entity when there is no other option, but in certain cases it is necessary from the larger point of view to do so. At least we were used to it especially in cases of big financial (or another) institutions, which are too big to fail, and it might be reasonable to "save" these entities to prevent bigger economic and social loss. For example, when bank fails, then many creditors lose their savings (although there is the deposit guarantee schemes), so they might stop using banking system, many people would lose their jobs (extra social expenses for state). This will all lead to reduce investing money for investors or consumers and that's basically wrong for economy itself. On the other hand, state aid is highly negative for competition, because all those private entities without any need for state aid are disadvantaged. And finally, its taxpayer's money, used for state aid and its big state expenditure for any country. The only way how to maintain good and healthy economic system without state aid is prevention. One of the preventions is Single resolution mechanism.
\end{abstract}

Key words: state aid; single resolution mechanism; bank recovery; taxpayers; bail in.

JEL Classification: K22

\footnotetext{
* JUDr. Michal Janovec, Ph.D., assistant professor at the financial law department of the Faculty of Law, Masaryk University, Brno, Czech Republic. Specializes mainly in the area of the financial law in general, particularly financial market law and also area of bankruptcy.

Contact email: michal.janovec@law.muni.cz; ORCID: 0000-0002-6565-4043.
} 


\section{Introduction}

This article goal is to determine the state aid and state expenditures regarding bail out (taxpayers pay for the saving of the bank). The resolution mechanism brings new ways and possibilities how to exclude the state aid together with keeping the financial market safe without failing of the financial institutions. The methods of description, analysis, comparison, and synthesis were used for writing this contribution.

Unlike the USA, most European countries did not have any special crisis mode (for financial system) before 2008. Such modes were introduced in reaction to the crisis, and they are now being modified so that the BRRD Directive can be implemented [Véron 2015: 11].

The single set of rules harmonised, to a certain extent, internal legal norms in member countries and there are now common instruments and powers that member countries can make use of. National supervisors, nevertheless, do have some freedom to decide how they will use them and in what way they will use domestic mechanisms of financing [Single Resolution Mechanism 2021].

In comparison with the traditional insolvency proceeding, which is governed by national legal norms, Pillar 2 of banking union ${ }^{1}$ offers a more flexible and quicker way of tackling problematic situations during a crisis of financial institutions. The resolution approach to crisis management also takes into account the fact that it may take place before legal conditions for bankruptcy are fulfilled, thereby incurring less damage to creditors in the resolution mechanism (if compared with the insolvency proceeding). Having accepted the Single Resolution Mechanism (hereinafter the 'SRM'), the EU had to reorganise and liquidate some credit institutions (in connection with the Directive 2001/24/EC of the European Parliament and of the Council of 4th April 2001 on the reorganisation and winding up of credit institutions).

Insolvency (bankruptcy) proceedings are part of civil lawsuit and its legislation is part of civil procedure. Its distinctive feature is the fact that it combines action and execution proceedings; it settles disputes and it results in the settlement of assets among a number of entities, which is typical of some non-contentious suits. The objective of the proceeding is to settle property (asset) relations to entities affected by the debtor's bankruptcy or insolvency and to satisfy proportionally the bankrupt's creditors [Winterová 2011: 592598].

\footnotetext{
${ }^{1}$ Banking Union is essentially an integrated financial framework based on three pillars. The first one is the Single Supervisory Mechanism, the second is the Single Resolution Mechanism, and finally the third one is the Common Deposit Guarantee Scheme. They are based on several European directives and regulations.
} 
In the insolvency proceeding is employed either the principle of reorganisation (to put it simply, there is an agreement with the creditors to lower the debt burden) or the institution is liquidated (liquidation outside an insolvency proceeding or bankruptcy within an insolvency proceeding) and the losses are divided among creditors, or both. In any case, the creditors and shareholders do not get full coverage of their claims. Nonetheless, experience from several crises (ex. the Lehman Brothers bankruptcy-the biggest bankruptcy ever) suggests that insolvency laws are not an effective way to deal with failures in financial institutions. They do not take into account the necessity to avoid disrupting the financial stability; they do not ensure the basic services, nor do they provide enough protection for depositors. An insolvency procedure takes more time and if reorganisation is opted for, it entails lengthy negotiations and agreements with creditors concerning potential losses of debtors and creditors connected with the delay, the costs and the outcome [Services of European Commission Directorate General, 2011: 2].

I would add that I consider reorganisation the most economical way of solving the problem of insolvency of financial institutions because it promises higher or equal satisfaction of creditors of the same rank when compared with bankruptcy (which is only a liquidating solution of a failure). Yet, the resolution mechanism of crisis management is overall more suitable and effective if it is applicable and applied in time.

The traditional mechanism of insolvency could disrupt the bank's capacity to provide clients with payment services, which could potentially lead to far-reaching economic consequences [Machelski 2013: 3].

The Single Resolution Mechanism, created by this pillar of banking union, is comprised of two crucial documents and one intergovernmental agreement. The two documents are the BRRD Directive ${ }^{2}$ supplemented by the SRM Regulation ${ }^{3}$. These two documents determine the basic operation of the Single Resolution Mechanism (planning, well-timed interventions, resolution objectives - remedial solution to crises, a set of instruments to be applied in order to achieve the objectives etc.) with its adequate organisationalinstitutional arrangement. This pillar consists of the Resolution Board and the Resolution

2 Directive 2014/59/EU of the European Parliament and of the Council of 15th May 2014 establishing a framework for the recovery and resolution of credit institutions and investment firms and amending Council Directive 82/891/EEC, and Directives 2001/24/EC, 2002/47/EC, 2004/25/EC, 2005/56/EC, 2007/36/EC, 2011/35/EU, 2012/30/EU and 2013/30/EU, and Regulations (EU) No. 1093/2010 and (EU) No. 648/2012, of the European Parliament and of the Council. Bank Recovery and Resolution Directive (hereinafter the BRRD Directive').

${ }^{3}$ Regulation (EU) No. 806/2014 of the European Parliament and of the Council of 15th July 2014 establishing uniform rules and a uniform procedure for the resolution of credit institutions and certain investment firms in the framework of a Single Resolution Mechanism and a single Resolution Fund and amending Regulation (EU) No. 1093/2010 (hereinafter the 'SRM Regulation'). 
Fund, established by the SRM Regulation. The BRRD Directive, on the other hand, opened the door to the establishment of national resolution authorities and national resolution funds.

The SRM Regulation also establishes the Single Resolution Fund (under the Single Resolution Board but financed via a special document called the Intergovernmental Agreement of 21st May 2014; hereinafter the 'IGA')4. IGA regulates some special rules including the system of operation and financing of this fund-it is primarily financed by the banking sector.

National resolution authorities are endowed with powers to apply resolution instruments and to execute resolution power. They can be set up within the central bank, a ministry or even another public institution established with the same aim. Resolution funds are established as bodies that should finance the resolution policy. The resolution board is authorised to decide which resolution instrument to apply in a particular emergency.

EBA play an important role, too, for its task is to create binding technical norms, instructions and reports regarding the main areas of remedial mechanisms and the crisis management of banks.

\section{Single Resolution Board (the SRB)}

It is an institution with legal personality, which is located in Brussels and was established at the beginning of 2015. It became fully operational on 1st January 2016. The head of the board is the Chair and there are also the Vice-Chair and 4 other members. The SRM is responsible for centralisation of most of the decision-making process and powers of resolution (rescue) measures for insolvent credit institutions (or for those credit institutions where insolvency is about to happen). This board plays a key role if insolvency has happened or is about to happen because it accepts decisions to ensure resolutions of failing banks with minimum costs to taxpayers. It is essentially an administrative parallel of a judicial ruling declaring insolvency. The SRB is directly responsible for creating and realising resolution plans for important banks and is also responsible for all resolutions (regardless of the size of the bank) if it is necessary to use money from the SRF. It is

\footnotetext{
${ }^{4}$ The Intergovernmental Agreement was signed by 26 member countries (all EU countries with the exception of Sweden). In the accompanying declaration they stated that they intended to ratify the agreement in such a way as to enable the establishment of the Single Resolution Fund by the $1^{\text {st }}$ January 2016. Member countries outside the Eurozone that signed the agreement will have to accept the rights and obligations only when they join the Single Supervisory Mechanism and the Single Resolution Mechanism.
} 
ultimately responsible for all banks in banking union and it can therefore exercise its powers towards any bank. In the true sense of the word they are not single and separately acting bodies (unlike the Supervisory Board within the SSM) since they must co-exist with domestic measures to organise and finance the process of resolution; in other words, they must strongly co-operate with national resolution authorities.

The resolution board has completed the first phase (January 2015-1st January 2016) ${ }^{5}$ of creating resolution plans, gathering information and co-operating with national resolution authorities. At present, it is in the second phase, which started on the 1st January 2016 and the SRB is now fully operational with a complete set of resolution powers and responsibilities ${ }^{6}$. The final stage will be completed when the transfer and mutualisation of contributions to the SRF are applicable according to the Intergovernmental Agreement, which must, however, be ratified by all the participating countries first ${ }^{7}$.

Mutualisation refers to the process of making use of financing mechanisms in member states when solving a crisis at the level of a group. A general contribution is paid first through the financing mechanism, which is then divided among individual domestic financing mechanisms. The financing mechanism is then a system consisting of the national resolution fund, other states' financing mechanisms, possibilities of lending money between financing mechanisms of member countries and mutualisation of financing mechanisms of member countries [Čundrlík 2014: 22-23].

\section{The supranational Singre Resolution Fund (the SRF)}

This institution is going to be used to solve crises in banks which find themselves on the verge of bankruptcy with all the other options having been tried. Another condition is that the shareholders and private creditors have contributed to the recovery attempts. This authority is financed by banking institutions and its creation will last for eight years (i.e. the end is scheduled to 2024). The funds available in the SRF should reach at least $1 \%$ of covered deposits of all credit institutions of banking union member countries. It is expected that the fund will have about 55 billion EUR at its disposal. Individual

\footnotetext{
${ }^{5}$ Cf art. 99 par. 3 of the SRM Regulation, which says: the provisions relating to the power of the Board to collect information and cooperate with national resolution authorities in order to create resolution plans shall apply from $1^{\text {st }}$ January 2015.

${ }^{6}$ A provision relating crisis management, timely interventions, regulations, and instruments to solve crises, including the involvement of shareholders and creditors.

${ }^{7}$ The Agreement will come into effect once it has been ratified by member countries taking part in the Single Supervision Mechanism and the Single Resolution Mechanism, representing $90 \%$ of the total of votes of all participating member countries. This agreement has been ratified by all member countries apart from Sweden.
} 
contributions of each bank will be calculated according to the ratio of the total amount of its liabilities (excluding the capital and covered deposits) to the aggregate liabilities (again excluding the capital and covered deposits) of all the credit institutions authorised in the participating member countries. The calculation process will also take into consideration the risks taken by the given institution [Single resolution mechanism 2014].

Contributions from banks will be received by the participating member countries via their national funds and then transferred to the SRF, which will be activated only if the principles stipulated in the BRRD Directive and the SRM Regulation are observed and if shareholders and private creditors take part in the recovery plans. These national funds should gradually, during the eight-year transition period, merge, while the contributions collected by each national fund will be shared as well. This transfer and sharing of finance from the national resolution funds is regulated by the abovementioned Intergovernmental Agreement (the IGA). Before the SRF has enough finance, the system of financing is ensured by thanks to domestic funds based on banking contributions, alternatively from the European Stability Mechanism. Another option is to transfer money from one national resolution fund to another; if that happens, the help is financed from the contributions coming from the banking sector.

\section{The resolution mechanism}

As far as the resolution mechanism is concerned, it is a co-operative effort of several bodies within the SRM: the ECB as the supervisory body within the SSM, the SRB consisting of national resolution authorities' representatives from the participating countries (it prepares and issues resolution decisions), the European Commission and the Council of the EU (these two can raise objections to decisions made by the SRB; if the decision grants state support or support from the SRF, the Commission must supply a positive answer), and, last but not least, the SRF, which provides finance for the resolution policy $^{8}$.

\footnotetext{
${ }^{8}$ Cf. art. 19, par 1 of the SRM Regulation: 'Where resolution action involves the granting of State aid pursuant to Article 107(1) TFEU or of Fund aid in accordance with paragraph 3 of this Article, the adoption of the resolution scheme under Article 18(6) of this Regulation shall not take place until such time as the Commission has adopted a positive or conditional decision concerning the compatibility of the use of such aid with the internal market.' According to art. 19, par. 3, subparagraph 4 of the same document: 'The Commission shall adopt a decision on the compatibility of the use of the Fund with the internal market, which shall be addressed to the Board'; (subparagraph no.7 deals with negative decisions by the Commission). According to art. 19, par. 10 of the same document the SRB may adopt a different decision from the one of the Commission if exceptional circumstances justify it. In other cases the link to the Commission is not required.
} 
The ECB informs the SRB that there is a credit institution on the verge of bankruptcy. Even the SRF can make such a decision if it informs the ECB and the ECB does not react in any way. The SRB decides whether it is in the public interest to apply the resolution mechanism and whether it is possible to solve the crisis within the private-law sector. If the conditions are not met, the bank is forced into liquidation according to the local legal norms. In the opposite case, the SRB accepts a resolution mechanism deciding on the instruments to be used and deciding also whether to ask the SRF for help. If the European Commission or the Council of the EU do not raise any objections and if it is not necessary to raise the finance stated in the mechanism, the decision comes into force within 24 hours of approval.

The Council of the EU appoints the SRB members; it determines which way the bankingsector contributions to the SRF are made and it raises objections to proposed resolution schemes that are supposed to deal with a crisis.

The Commission confirms decisions made by the SRB or it may raise an objection to some of their aspects, which the SRB was supposed to consider on its own. If the criterion of the public interest of the resolution is not met, or if the amount of finance to be used from the SRF has changed, the Commission suggests that the objection should be raised by the Council. If the resolution entails granting state aid pursuant to Article 107 of the TFEU or aid from the SRF, it can only be accepted once the Commission has adopted a positive or conditional decision regarding the compatibility of this aid with the internal market.

National institutions of the participating member states are responsible for creating and accepting resolution plans of those banks which do not fall under the scope of the SRB. Decisions made by the SRB are addressed to national resolution authorities that put them into practice according to instructions issued by the SRB; in case these instructions are not followed properly, the SRB can address its decisions to failing banks themselves-in other words, the decisions affect the private sector directly.

This way of solving crises originates in the fundamental principle of banking union namely the fact that any negative consequences of bankrupt credit institutions will be borne by the credit institutions and the financial sector rather than by taxpayers.

The crucial aspect of the abovementioned mechanism is the creation of a single procedure to follow when dealing with international and systemically important banks. If there is a crisis, it is undoubtedly more appropriate to act identically and to apply the same procedure in all the countries where the institution is active-thus, one can avoid disparate decisions within the EU which result in longer delays and higher costs. Other benefits 
include restoration of confidence in the financial sector, less panic among depositors and, to a certain extent, prevention of diffusion of the crisis to those states which do not participate in banking union. The mechanism ensures that banks are only a little dependent on the states and their budgets; as a result, any resolution adopted should only exert a marginal impact on the economy of the given state-in the past, the public method used to harm the real economy much more noticeably. The Supervisory Board is supposed to link the supranational resolution system with the system of supervision of the ECB with a view to centralising and unifying supervisory activities and potential trouble solving, which should bring considerable benefits to the single internal market and its financial services.

The establishment of the Single Resolution Board (after the SRM Regulation came into effect on the 19th August 2014) and the coming into effect of the BRRD Directive (which, from January 2015 onwards provided the impetus to establish national resolution authorities) coincide, which creates the opportunity to find out the best way of cooperation between these two systems and to take into account the tried and tested methods for the establishment of national resolution authorities [Deposit Guarantee Schemes, 2021].

The SRM Regulation' also anticipates the establishment of an Appeal Panel, which will arbitrate appeals against decisions made by the SRB.

\section{The BRRD Directive}

As it was mentioned above, it was no longer acceptable for failing banking institutions to receive support from public budgets since such support was essentially provided by taxpayers and it constituted a very heavy burden to the economy of a particular country. Naturally, the situation greatly undermined economic competition because the state provided unprecedented support to only those private institutions that had problems; problem-free institutions did not receive any finance and were thus disadvantaged, to put it another way, they were 'punished' for having behaved more responsibly. This financial support is colloquially referred to as a 'bailout'-financial help from the outside. Such help is, however, unacceptable and from the macroeconomic point of view also unbearable even if there is a real danger of systemic failures in economy potentially resulting in even greater public expenses should large financial institutions become insolvent (for instance the finance accumulated in deposit insurance funds would not suffice to ensure mandatory

\footnotetext{
${ }^{9}$ Cf. art. 85 and 86 of the SRM Regulation.
} 
payments and states would have to support these insurance funds from public budgets again).

These are the reasons for the resolution mechanism and the regulatory framework for crisis management of credit institutions ${ }^{10}$ (mainly banks, credit unions and securities dealers). The objective of the use of resolution instruments according to the BRRD Directive is the maintenance of vital functions of credit institutions. These vital functions include sets of indispensable services and operations whose disruption would upset financial stability in one or more EU countries and would disturb the services of macroeconomic importance. Furthermore, the instruments are supposed to prevent negative systemic consequences of problems of credit institutions, such as crisis contagion. They strive to protect public financial funds, the clients' finances, credit depositors and investors. As banks are, without doubt, the most important credit institutions, I from now on talk about banks even in cases where I talk about all credit institutions.

This directive does not affect only the participating countries of banking union - some provisions apply to all member countries (e.g. the obligation to set up national resolution authorities that are supposed to create resolution plans for crisis management, the obligation to set up national resolution funds, the obligation for all EU banks to prepare recovery plans).

The BBRD introduces one extremely important instrument, namely the 'bail-in'-financing the resolution plan from the inside, sponsored by the shareholders and the main creditors. It is a way of motivating them to conduct business in a less hazardous manner as well as a way of forcing them to monitor the bank and to prevent any potential financial problems, which could possibly lead to financial loss for taxpayers.

The underlying principle of this instrument is the involvement of certain people in sharing financial loss of the bank and in the subsequent resolution, too-the recapitalisation of internal sources of the bank through a very detailed hierarchy of loss bearers: the first are shareholders followed by creditors (the priority is assigned according to the size of their claims, at the top are senior creditors). Creditors of the same rank are treated in the same way (as far as bearing the loss is concerned)-no creditor can receive less than what they would receive in an insolvency proceeding and insured deposits are fully protected. The shareholders' share may be partially or fully reduced (the so-called 'haircut'); another option is to reduce the creditors' claims (partial or full debt remission); alternatively, the

10 'Credit institution' is defined in point (1) of Article 4(1) of the CRR Regulation. A credit institution means an undertaking, the business of which is to take deposits or other repayable funds from the public and to grant credits for its own account. 
claims may be transferred into business shares for the benefit of creditors, which actually results in that reduction of business shares of the shareholders. Only then can the national resolution fund step in, and it can finance the costs on its own; or, possibly, the finance may come from the SRF for banking union members. The last resort is a theoretical possibility of finding financial support from public budgets if several criteria are met, as specified below. Typically, the statutory bodies and top executives are replaced if their presence is not necessary for the objective of the resolution plan. The obligation to cooperate towards reaching the goal of the resolution plan applies to the original as well as the newly appointed executives of the credit institution.

International co-operation is an absolute must in case of banking groups whose activities reach beyond the EU. In this case there must be bilateral and multilateral agreements regulating co-operation among national resolution authorities and their opposite numbers in non-EU countries. The proposals for co-operation are submitted to the Council of the EU by the European Commission.

The BBRD Directive deals with three phases: $a /$ the preventive phase, $b /$ the early intervention phase and $\mathrm{c}$ / the recovery phase (in case of a failing bank) or the resolution phase (in case of an already insolvent bank)

As for prevention, the newly adopted feature maintains that all banks in the EU must prepare their own recovery plans which must be updated every 12 months. These plans include a detailed analysis of methods and regulations to be accepted in an unfavourable financial situation; they work with several variants of macro-economic and financial problems. These model situations include the conditions of early intervention and recovery measures.

The authorised bodies together with supervisory bodies keep creating resolution plans. A resolution plan stipulates regulations that a particular body can adopt when dealing with a crisis; part of it is also an analysis of conditions on which a bank can apply for the use of central bank facilities and determine assets that should serve as insurance (not as a bailout, though) [Němec - Tornová 2014].

As far as the early intervention and recovery plans are concerned, these are sets of regulations and powers given to a national resolution authority, which should intervene before the actual insolvency takes place. The situation is still solvable-for example via the so-called 'soft-law' instruments. In order to stabilise and recover an institution, the national resolution authority can ask for a reform or debt restructuring in co-operation with the creditors. An early intervention is often used if a credit institution does not fulfil certain 
criteria of prudential business (e.g. capital requirements, liquidity rules, etc.) or if it is very probable that the rules will soon be violated because the liquidity situation is getting worse, the loans are not being repaid and there is a significant increase in other sources of financing. An early intervention and recovery plans attempt to keep the key banking transactions in operation and quickly stabilise the credit institution.

It is also possible to appoint a so-called special manager, who is essentially one of the crisis management instruments, but it is not a resolution instrument, which is why it is considered to be an early intervention instrument. Also, there is a question whether this would actually be a case of receivership for the given credit institution (the kind that a national supervisory authority can impose) or whether it would be parallel receivership; the question, in other words, might be: would the legal concept of receivership not lose some of its importance? While it is evident that these are two different instruments to deal with failing banks (the appointment is performed by two different bodies); yet, in some ways the activities of the special manager and the receiver overlap. It cannot probably cause any problems in the Czech Republic, where the local resolution authority is, admittedly, an independent body, but it exists within the CNB, and in that case it hardly matters whether it is receivership based on the current legal norms or an instrument imposed by the national resolution authority based on the BRDD Directive.

The resolution phase $^{11}$ is applicable if the problem of the bank is so grave that any recovery attempt is doomed; the national resolution authority may proceed in one of the following ways depending on the plans the bank in question has. It may:

- sell part of its business activities - in the resolution phase it is possible to sell a partial or a complete number of shares or assets, rights, or third-party liabilities even without the consent of the statutory bodies or the bank's shareholders. The profit from the transaction is paid, after the expenses have been deducted, to the shareholders involved; alternatively, in case of assets, rights and liabilities, the proceeds from the transfer are used to the benefit of the bank in the resolution phase.

- set up a bridge bank -a bridge bank maintains the most important functions within the resolution phase (i.e. it must carry out a temporary transfer of assets to a public-owned entity-owned by one or more public authorities of the given country) so that the bank can fully recover or its liquidation may happen. What needs to be resolved, though, is the issue of the public-owned bank. Is the bridge

\footnotetext{
${ }^{11} \mathrm{Cf}$. Title IV of the BRRD Directive, where can be found resolution instruments.
} 
bank supposed to have been established prior to the resolution process or can it be established ad hoc? The former seems to be the only viable option but this is hardly a popular choice. On the other hand, it is not possible to establish a bridge bank within a very short period due to all Union as well as national legal norms and regulations that must be observed so that an institution can receive a banking licence. This process typically takes at least a few months.

- separate good from bad assets - depreciated assets of the institution in the resolution phase or in the bridge bank scheme can be transferred to an entity for asset management-this entity is again a public-owned one that 'consumes' bad assets so that the bank can fully recover or it may be sold. This instrument is only to be used in combination with other instruments to avoid unfair competitive advantage for the failing bank.

- opt for a bail-in instrument - as described above, the idea is to get shareholders and creditors involved in the process of resolution; to convert the debt to shares or to write the debt off. The loss should primarily be absorbed by the MREL capital reserve (see below). Subsequently, the loss affects the shareholders, whose shares are cancelled, transferred or their value is lowered. If the measures turn out to be insufficient, the debt may be converted and written off (primarily the subordinated debt) as the capital.

The process of recapitalisation should involve as wide a spectre as possible of unsecured debts of the failing bank-exceptions include secured deposits, debts towards the employees, debts for goods, services crucial for the operation of the bank, and debts from the pension system [Němec - Tornová 2014].

\section{The national resolution fund}

It is a body which comes into action as an instrument of prevention, early intervention as well as resolution. Every member country must create its own resolution fund financed by credit institutions. It can be used if these institutions experience serious problems. Each institution contributes to the fund according to its obligations and the risks it takes. The total amount of finance in the fund is the same as in the SRF: at least 1\% of covered deposits of all credit institutions in a particular country. The fund is maintained through regular contributions, one-off contributions, gaining money in the financial market, loans from other mechanisms of financing the process of resolution, provisions of recoverable financial help, and public budget grants. 
- National resolution funds provide temporary support to failing banks (loans, collaterals, the purchase of assets or provision of the capital for bridge banks);

- They can only be used to compensate shareholders and creditors if the involvement of resolution creates a higher loss than what would have been caused in an insolvency proceeding according to national legal norms.

- Under exceptional circumstances the fund can be used to absorb losses or to recapitalise banks.

Financial help from this fund can be used only after the shareholders and creditors have incurred losses of at least $8 \%$ of the total liabilities of the bank. The help is then restricted to not more than $5 \%$ of the total liabilities of the bank. Only then, if the support proves to be insufficient and if the bail-in instrument has been used as well, is it possible to look for alternative ways of financing; e.g. in a situation where a wide recapitalization on the part of the creditors would lead to financial instability. It is also possible to apply for public support (a bail-out) but only if all the other options have been tried and the amount of bailin cover has reached $8 \%$. Also, it can only happen under extraordinary circumstances and the approval from the European Commission is mandatory.

\section{The minimum requirement for own funds and eligible liabilities - MREL}

In November 2014 EBA initiated a public consultation on draft regulatory technical standards (RTS) which lay down the minimum requirements for own funds and eligible liabilities (hereinafter 'MREL'). MREL has been set up to prevent institutions from structuring their liabilities in such a way as to restrict the effectiveness of the bail-in instrument or any other instruments introduced by the BRRD Directive, in which it says that banks are obliged to fulfil 'robust' minimum capital and eligible liabilities requirements [EBA, 2021]. The proposals made by the RTS also take into account the impact of the deposit insurance system and expenses on the resolution plan.

Technical standards clarify how the capital requirements on institutions should be linked with MREL needed to absorb losses, and, if need be, to recapitalise banks after the resolution process has finished. National resolution authorities base their activities on the supervisor's assessment of the amount of loss (to be absorbed by the bank) and the capital (needed by the bank to operate).

National resolution authorities (in the Czech Republic it is Czech National Bank) are supposed to lay down MREL in such a way as to ensure the execution of the resolution plan of a given bank. The crucial questions connected with this are how robust MREL 
should be and whether adequate MREL is to be determined by trial and error or rather via an expert analysis of a specific bank. It is the resolution plan that may state when (for which liabilities) it would not be feasible to opt for a bail in (albeit it would be legally possible). In cases like this, national resolution authorities must increase MREL or adopt other measures (e.g. a measure to change the order of liabilities in insolvency).

In the Czech Republic, MREL has been set up for banks and credit unions with registered seat in the Czech Republic, but it is always based on an individual approach in accordance with the preferred resolution strategy ${ }^{12}$. The CNB sets MREL for institutions in its area of competence on an annual basis. The requirement must be met on 1 January 2024 at the latest. In order to ensure a steady increase in own funds and eligible liabilities to the required level, the CNB also sets a binding intermediate target in accordance with the requirement of Directive (EU) 2019/879. Institutions are obliged to meet this target as of 1 January 2022 at the latest [Czech National Bank]. For the financial institutions whose resolution plan assumes the use of resolution measures in the event of their failure, the CNB has already set the MREL as the sum of the loss absorption amount (LAA) and the recapitalisation amount (RCA) [Czech National Bank]. There is an extra capital requirement called combined buffer requirement (CBR) and it is reflected neither in the LAA nor in the RCA and must be met additionally to the MREL expressed as a percentage of the TREA (the stacking order approach) ${ }^{13}$. This extra capital buffer (CBR) must be separated from MREL, just to ensure, there will be enough (and separated) capital buffers to be used in stress situation of the banks.

The BRRD Directive brings new and highly effective instruments and ways to solve problems. To a certain extent it destroys the traditional image of public financing as a means of being rescued if the situation gets from bad to worse. The traditional way of dealing with crises did not force leading representatives of credit institutions to behave responsibly enough. In other words, it did not provide enough motivation to ensure that the credit institutions maintain a balanced budget and they refrain from entering too risky business.

\footnotetext{
12 Where the CNB in its resolvability assessment concludes that liquidation of the institution or group under normal insolvency or winding-up proceedings is both feasible and credible, the minimum requirement for own funds and eligible liabilities will be limited so that it does not exceed the amount sufficient to absorb losses set by the supervisory authority. Exceptions may include specific situations where the CNB determines that a positive recapitalisation amount is necessary on the grounds that liquidation would not achieve the resolution objectives to the same extent as an alternative resolution strategy.

${ }^{13}$ The total risk exposure amount calculated in accordance with Article 92(3) of Regulation (EU) no. $575 / 2013$.
} 
Coppola has it that shareholders and creditors will always try everything they can to avoid using the bail-in instrument since they will not accept the loss connected with it. He is convinced that the BRRD Directive, which imposes the loss on creditors rather than taxpayers, will eventually lead to a high number of lawsuits. In addition, there seem to be a lot of gaps and exceptional circumstances as far bonds and shares are concerned which will undoubtedly prolong the lawsuits [Coppola, 2015]. This all will turn to be a very heavy burden for the structure of the EU. There have already been some cases where the bail-in instrument with cross-border application ${ }^{14}$ was used and, likely, there will soon be others (Italian and Greek banks). The biggest danger for the EU thus might be lawsuits following the application of the BRRD Directive and its bail-in instrument.

\section{Conclusion}

I do not think, though, that the situation is going to be that serious. Every new regulation and every new instrument, particularly if it demolishes the good old ways, must necessarily arouse a great deal of indignation and an increase in media coverage and legal activity. It seems to me that these problems are nothing more than an unavoidable reaction surrounding the introduction of a new concept. It is even more problematic since a certain group of people might incur substantial losses. This regulation, however, appears to be truly necessary in order to maintain a stable financial system in the EU and to support the existence of a single market. Once the European Court of Justice has been made a major decision surrounding the use of the bail-in instrument (particularly if the case is international and the practice of the courts clear up any hazy areas in the BRRD Directive), the practice will eventually absorb and establish this new piece of legislation. This new legal regulation will gradually be accepted by both credit institutions and the public, and the amount of the shareholders' displeasure connected with the bail-in instrument will eventually subside. The instrument will hopefully become so universal that creditors and shareholders will always bear it in mind when deciding on the next step in investment. Ultimately, the number of lawsuits should decrease, and financial market stability should move the opposite direction.

${ }^{14}$ E.g. the Dexia Group, a bank owned by French and Belgian owners, and KA Finanz AG, an Austrian bank owned by the Dexia Group. The Dexia Group tried to make Austrian taxpayers cover its losses by refusing the bail-in instrument for its subsidiary in Austria, which was rejected by the Austrian Supreme Court. Another example is an Austrian bank called Hypo Alpe Adria: the Austrian Ministry of Finance announced a debt moratorium on the bank's creditors, most of whom were German and Austrian banks and other financial institutions including the World Bank. There is also a great amount of pressure from German banks which want their own state to offer as much support as possible in their lawsuit against Austria. 


\section{References}

Čundrlík, L., Právny rámec riešenia krízových situácií úverových inštitúcií v EÚ jako bazálny inštrument predchádzenia finančnej nestability [Legal framework for solving crisis situations in credit institutions in the EU as a basic tool to prevent financial instability], in: Finančné a sociálne aspekty dlhovej krízy z pohladu ekonómie a práva [Financial and social aspects of the debt crisis from the point of view of economics and law], Bratislava: Ekonomický ústav SAV, 2014

Machelski, T., Banking resolution as an economic intervention. Dny práva 2012. Sborník z vědecké konference [Law Days 2012. Proceedings of the scientific conference], Brno: Masaryk University, 2013

Němec, L., Tornová, J., BRRD: Nová regulace krizového řízení bank [New regulation of crisis management of banks]. Bankovnictví online [Banking online], 2014

Available at: http://www.bankovnictvionline.cz/banky-finance/brrd-nova-regulacekrizoveho-rizeni-bank, accessed: $22^{\text {nd }}$ November 2021

Véron, N.: Europe's radical banking union. Bruegel essay and lecture series. Brussels: Bruegel, 2015

Winterová, A. et al., Civilní právo procesní (Law of Civil procedure). 6th revised ed. Prague: Linde Praha, 2011

\section{Legal Acts}

Directive 2014/59/EU of the European Parliament and of the Council of 15th May 2014 establishing a framework for the recovery and resolution of credit institutions and investment firms and amending Council Directive 82/891/EEC, and Directives 2001/24/EC, 2002/47/EC, 2004/25/EC, 2005/56/EC, 2007/36/EC, 2011/35/EU, 2012/30/EU and 2013/30/EU

Regulations (EU) No. 1093/2010 and (EU) No. 648/2012, of the European Parliament and of the Council. Bank Recovery and Resolution Directive (hereinafter the BRRD Directive')

Regulation (EU) No. 806/2014 of the European Parliament and of the Council of 15th July 2014 establishing uniform rules and a uniform procedure for the resolution of credit institutions and certain investment firms in the framework of a Single Resolution Mechanism and a single Resolution Fund and amending Regulation (EU) No. 1093/2010 (hereinafter the 'SRM Regulation')

\section{Other Official Documents}

European commission, Deposit Guarantee Schemes, 2021

Available at:

http://srb.europa.eu/, accessed: 22 $2^{\text {nd }}$ November 2021

Services of European Commission Directorate, General Internal Market, Discussion paper on the debt write-down tool - bail-in (A working document), Brussels 2011

\section{Internet Resources}

Coppola, F.: When bad banks fight each other. Forbes, 22.5.2015 [online]. 2015.

Available at:

http://www.forbes.com/sites/francescoppola/2015/05/22/when-bad-banks-fight-eachother/, accessed: $22^{\text {nd }}$ November 2021

Czech National Bank, General approach of the Czech National Bank to setting a minimum requirement for own funds and eligible liabilities (MREL)

Available at:

https://www.cnb.cz/en/resolution/general-approach-of-the-czech-national-bank-to-setting-

a-minimum-requirement-for-own-funds-and-eligible-liabilities-mrel/, accessed: $\quad 22^{\text {nd }}$ November 2021

EBA. EBA consults on criteria for determining the minimum requirement for own funds and eligible liabilities (MREL), 2014

Available at:

https://www.eba.europa.eu/-/eba-consults-on-criteria-for-determining-the-minimumrequirement-for-own-funds-and-eligible-liabilities-mrel-, accessed: $22^{\text {nd }}$ November 2021

Single Resolution Mechanism. The European Council. The Council of the European Union 
Available at:

http://www.consilium.europa.eu/cs/policies/banking-union/single-resolution-mechanism/, accessed: $22^{\text {nd }}$ November 2021 